\title{
Analysis of the demand status and forecast of food cold chain in Beijing
}

\author{
Hongjie Lan, Yongbin Tian \\ School of Economics and Management, Beijing Jiaotong University (China) \\ bjlan@,bjtu.edu.cn; tyb1518@126.com
}

Received: October 2012

Accepted: February 2013

\section{Abstract:}

Purpose: Food cold chain is very important for ensuring food safety and decreasing the loss in the supply process. It is also benefit for the citizen, because cold chain could promise the food safety and the demand of the special cold food. Beijing, as the capital, the level of food chain is high, compared to other cities, and analysis of the demand status and forecast of food cold chain in Beijing is necessary, it could direct the scientific and health development of cold chain all over our country.

Design/methodology/approach: In this paper, in accordance with the investigation, we analysis the demand status of food cold chain from two aspects, then according to the status, we forecast the demand of refrigerated cars and warehouse for food cold chain in Beijing with the multivariate statistics.

Findings: From the analysis of the paper, we can see that the need of cold chain logistics grows rapidly, but most consumers are lack of the awareness of the importance of the cold chain and many companies cannot bear the huge investment, it make the gap of the resources of cold chain logistics large and cannot meet the normal need of cold chain logistics in Beijing.

Originality/value: The result of this paper could support the relative enterprise to run business in terms of the refrigerated car and warehouse.

Keywords: food cold chain, demand forecast, refrigerated cars, refrigerated warehouse 


\section{Introduction}

Being closely relative to the health of Human Beings, food safety has gained more and more attention from all countries. Not only can the frozen food guarantee the nutrition of food, but also can keep the food fresh. Beijing, as the capital of China, has a big food consumption, then research on the cold chain is necessary, Beijing should be concerned the hygiene and safety of the mass consumption food. Nowadays, with people's life standardization growing, consumers call for high level service from manufactures (Fang, Gao \& Fan, 2005). So enterprises must pay more attention on cold chain to protect the safety of food supply, then make cold chain logistics get great development as a special logistics.

What's more, the frozen food has its own characteristics, such as short shelf life, special demand for temperature and so on, which influence the distribution. If there is something wrong with the food safety, there will be a lot of problems (Su \& Li, 2007). So the frozen food distribution has been very important.

According to above, there will be large demand for frozen food, such as refrigerated cars, refrigerated warehouse and so on. In this paper, we will forecast the demand of refrigerated cars and refrigerated warehouse in Beijing based on the status of food cold chain of Beijing. The outcome of the forecast will be a reference for the enterprise of food cold chain and government.

\section{The demand status of food cold chain in Beijing}

According to Glossary of Logistics (GB/T18354, 2006), the definition of cold chain is that according to the characteristics of production, in order to keep its main quality, it need to use a special logistics network which is must be keep low temperature situation from the production to the consumption(Hua, 2010; Liu \& Qiu, 2007). Food cold chain is a special kind logistics which is an application in food. And as a special supply chain, the research object is food which is perishable. Food cold chain is referring to meat, poultry, vegetables, fruits, milk production and so on. In this paper, from two aspects the refrigerated warehouse and the refrigerated cars, according the existing data, the research will analysis the demand status of food cold chain in Beijing, then predict the demand of the refrigerated warehouse and the refrigerated cars.

\subsection{The total status of cold chain logistics}

With the enhanced awareness of the continuous improvement of people's living standards and food safety, per capita consumption on cold chain-related food in Beijing is increasing year by year, the average consumption of the peasant family in Beijing as shown in Table 1. 


\begin{tabular}{|c|c|c|c|c|c|c|c|c|c|}
\hline Year & Pork & $\begin{array}{c}\text { Beef and } \\
\text { mutton }\end{array}$ & Poultry & Eggs & Vegetables & Fruits & $\begin{array}{c}\text { Milk } \\
\text { products }\end{array}$ & $\begin{array}{l}\text { Aquatic } \\
\text { products }\end{array}$ & Total \\
\hline 2010 & 13.3 & 4.2 & 3.2 & 10.5 & 97.9 & 39.7 & 11.3 & 4.9 & 185 \\
\hline 2009 & 13.9 & 4.6 & 3.4 & 11 & 95.6 & 43.5 & 12.7 & 5.7 & 190.4 \\
\hline 2008 & 12.4 & 3.9 & 3.4 & 10.3 & 99.1 & 36.3 & 11.5 & 4.9 & 181.8 \\
\hline 2007 & 12.1 & 4.7 & 2.9 & 9.3 & 91.1 & 37.4 & 14.6 & 5.2 & 177.3 \\
\hline 2006 & 14.3 & 4.8 & 2.4 & 9.2 & 89.1 & 36.2 & 14.6 & 5.1 & 175.7 \\
\hline
\end{tabular}

Table 1. The per capita consumption of the important necessity of the peasant family in Beijing (Unit: $\mathrm{kg}$ )

In the view of the wholesale market, the cold chain food's volume increased year by year, as shown in Table 2. In the wholesale market, every time the transaction of goods will lead to the occurrence of cold chain logistics activities, so the trading volume can well reflect the demand of cold chain logistics in Beijing. From the table, in recent years, the volume of food in Beijing cold chain has keep at a high level, if the beef and mutton meat, poultry, aquatic products, eggs, vegetable species, and some fruits need to be cold-chain transport, then Beijing cold chain logistics demand will be more than 16 million tons. The level of development of the existing cold chain enterprises in Beijing can't meet the demand. So it has huge development potential.

\begin{tabular}{|c|c|c|c|c|c|c|c|c|c|}
\hline Year & Pork & Beef and mutton & Poultry & Eggs & Vegetables & Fruits & Milk products & $\begin{array}{l}\text { Aquatic } \\
\text { products }\end{array}$ & Total \\
\hline 2010 & 388542 & 88080 & 70464 & 60402 & 353403 & 12394505 & 7488604 & 728654 & 21572654 \\
\hline 2009 & 383891 & 77784 & 65282 & 59943 & 312435 & 10966243 & 7145718 & 684877 & 19696173 \\
\hline 2008 & 353298 & 94629 & 76600 & 54431 & 263219 & 11043840 & 6188660 & 515223 & 18589900 \\
\hline 2007 & 344244 & 100638 & 88943 & 50143 & 223784 & 15116486 & 5527118 & 609425 & 22060781 \\
\hline 2006 & 387776 & 125344 & 114802 & 42517 & 193778 & 14800038 & 4889565 & 459021 & 21012841 \\
\hline
\end{tabular}

Table 2. The wholesale market trading volume of the food related to cold chain in Beijing (Unit: $t$ )

\subsection{The status of facilities and equipment of cold chain logistics}

There are many facilities and equipment in cold chain logistics, but one of the most important and that could reflect the capacity of cold chain logistics is refrigerated cars and refrigerated warehouse.

\section{The status of refrigerated cars}

Existing 2405 refrigerated cars in Beijing, as shown in Table 3. Mainly 2 ton refrigerated cars (containing less than 2 tons) .It's related to the city distribution on cold chain logistics in Beijing. Its demand has characteristics of a small batch, multi-volume. Table 4 shows the status of Beijing refrigerated cars in recent years, From the table, we can see the growth of refrigerated cars is more obvious, the number of refrigerated cars in 2010 is 1.8 times than in 2008, 2.3 times than in 2007, the proportion of refrigerated cars continue to grow. Although the total amount of refrigerated cars is increasing, but per capita is still relatively lower. In 2010, Beijing has population of 19.619 million, refrigerated cars belonging to per capita is 1.4 $\times 10^{-4}$ vehicles, which is equivalent to 7142 person use a refrigerated car, while the U.S. average is 1500 person use a refrigerated car, and Japan is about 867 people using a 
refrigerated car. Thus, compared to developed countries, Beijing's per capita number of refrigerated cars is much less. The lack of refrigerated cars hindered the improvement of people's living standard, also caused the loss of food, influencing food safety.

\begin{tabular}{|l|r|r|r|r|r|}
\hline Kinds of cars (tons) & $<=2 \mathrm{t}$ & \multicolumn{1}{|c|}{$2 \mathrm{t}-4 \mathrm{t}$} & \multicolumn{1}{|c|}{$4 \mathrm{t}-8 \mathrm{t}$} & \multicolumn{1}{|c|}{ Total $(\mathrm{t})$} \\
\hline Number (volume) & 1882 & 239 & 189 & 95 & 2405 \\
\hline Perception (\%) & 78.25 & 9.94 & 7.86 & 3.95 & 100 \\
\hline
\end{tabular}

Table 3. The number and perception of refrigerated cars in Beijing in 2010

\begin{tabular}{|c|r|c|c|}
\hline Year & $\begin{array}{c}\text { The quality of refrigerated } \\
\text { car(volume) }\end{array}$ & $\begin{array}{c}\text { The quality of freight } \\
\text { car(volume) }\end{array}$ & $\begin{array}{c}\text { The perception of refrigerated } \\
\text { car to freight car }\end{array}$ \\
\hline 2006 & 1061 & 177000 & $0.60 \%$ \\
\hline 2007 & 1307 & 176000 & $0.74 \%$ \\
\hline 2009 & 2405 & & \\
\hline
\end{tabular}

Table 4. The status of refrigerated cars in Beijing

\section{The status of refrigerated warehouse}

The paper did an investigation of 152 enterprises of cold chain logistics in Beijing, the current of the refrigerated warehouse resource is 665,000 tons. In addition, there is also some missing research of refrigerated warehouse resources. The industry experts estimate that the city refrigerated warehouse total resources is about $0.70-0.90$ million tons. According to incomplete statistics of the Beijing Institute of Food Science, the total refrigerated warehouse capacity of Beijing is 426,300 tons in 2009. In accordance with the lower limit of the existing refrigerated warehouse resources in Beijing is 0.7 million tons, it's an increase of 64.2 percent in 2010 than in 2009. In 2010, Beijing per capita has 0.0399 tons of refrigerated warehouse resources, which was only 5.7 percent of per capita in the United States. This shows that Beijing refrigerated warehouse resources has been rapid growth. On the other hand, the Beijing refrigerated warehouse resources also need to increase, it's still has a gap to developed countries.

\section{Analysis of the demand forecast of food cold chain in Beijing}

The facilities and equipment of cold chain logistics is developing with their demand at the same way, only in this way, the resources of cold chain logistics will be used fully and properly, and meet the requirement for the cold chain of the relevant food, which could ensure food safety.

\subsection{Analysis of the demand forecast of refrigerated cars}

\section{The theoretical value of max carrying capacity of the existing refrigerated cars}

We use the data in Table 3 to calculate the existing refrigerated cars' max carrying capacity in Beijing. Assume that the four kinds of refrigerated cars' maximal carrying capacity are 2 tons, 
4 tons, 8 tons and 10 tons respectively. Calculate each car's maximal carrying capacity when distributing once or twice per day.

\begin{tabular}{|c|c|c|c|c|c|c|}
\hline \multicolumn{2}{|c|}{ Kinds of cars (tons) } & $<=2 t$ & $2 t-4 t$ & $4 t-8 t$ & $>8 \mathrm{t}$ & \multirow{2}{*}{$\begin{array}{l}\text { total } \\
(\mathrm{t})\end{array}$} \\
\hline \multicolumn{2}{|c|}{ The calculated tons } & $2 \mathrm{t}$ & $4 \mathrm{t}$ & $8 \mathrm{t}$ & $10 \mathrm{t}$ & \\
\hline \multirow{2}{*}{ max carrying capacity per year } & Distribute once per day & 1373860 & 348940 & 551880 & 346750 & 2621430 \\
\hline & Distribute twice per day & 2747720 & 697880 & 1103760 & 693500 & 5242860 \\
\hline
\end{tabular}

Table 5 . The theoretical value of max carrying capacity of the existing refrigerated cars

As shown in Table 5, the theoretical value of max carrying capacity is 5.24 million tons when distributing twice per day, namely the annual carrying capacity is about 0.19 million tons. It has a very big disparity from the data in Table 1 and Table 2, which cannot meet the needs of the society.

If all the mutton meat, poultry, aquatic products (hypothesis $50 \%$ ), part of eggs (hypothesis $50 \%$ ), fruits (hypothesis $25 \%$ ) and fresh vegetables (hypothesis $25 \%$ ) are required cold chain transportation. According to the current urban road traffic management measures of Beijing city, the motor vehicles are forbidden during 6 and 23 o'clock within the forth-loop roads (including the forth-road). Additionally, in 2010, the urban population of Beijing is $86 \%$ (from the Beijing Municipal Bureau of statistics data: the urban population is 16.864 million, rural population is 2.755 million). Since most urban population live in the center of Beijing (within the forth-loop roads) and the average consumption amount of food is higher, this paper assumes that the tonnage transported by refrigerated trucks to the city center accounts for $70 \%$ of the total tonnage. This paper take the 1-ton deadweight and 2-ton deadweight for example, calculate the required number of refrigerated cars per day when distributing once in the city.

\section{The demand of refrigerated cars calculated via per capita consumption}

Take the data of 2010 as an example. Table 6 shows the per capita consumption of related cold chain food in 2010. The population of Beijing in 2010 is 19.619 million. We can get the total consumption of Beijing and the consumption within the forth-loop roads, thus the theoretical value of refrigerated cars needed can be calculated, as shown in Table 6.

Because the cold chain food needs to be transported by refrigerate cars at least once before reaching consumers (e.g. from the origin directly to the supermarket and then bought by consumers), while the more common situation is repeatedly refrigerated transportation from production enterprises to the wholesale business, wholesale business to retail enterprises. As a result, Table 6 calculates the minimum theoretical value. 


\begin{tabular}{|c|c|c|c|c|c|c|}
\hline \multirow{2}{*}{$\begin{array}{c}\text { Cold chain } \\
\text { Food }\end{array}$} & \multirow{2}{*}{$\begin{array}{l}\text { The whole } \\
\text { traffic } \\
\text { volume of } \\
\text { cold } \\
\text { chain(t) } \\
\end{array}$} & \multirow{2}{*}{$\begin{array}{c}\text { Traffic } \\
\text { volume } \\
\text { within the } \\
\text { forth-loop } \\
\text { roads(t) } \\
\end{array}$} & \multicolumn{2}{|c|}{$\begin{array}{c}\text { The number of refrigerated } \\
\text { cars (1t)needed(volume) }\end{array}$} & \multicolumn{2}{|c|}{$\begin{array}{l}\text { The number of refrigerated } \\
\text { cars ( } 2 \mathrm{t}) \text { needed(volume) }\end{array}$} \\
\hline & & & $\begin{array}{c}\text { Distribution } \\
\text { once per } \\
\text { day }\end{array}$ & $\begin{array}{c}\text { Distribution } \\
\text { twice per } \\
\text { day }\end{array}$ & $\begin{array}{c}\text { Distribution } \\
\text { twice per } \\
\text { day }\end{array}$ & $\begin{array}{c}\text { Distributio } \\
\text { n once per } \\
\text { day }\end{array}$ \\
\hline Pork & 260932.7 & 182652.9 & 500 & 250 & 250 & 125 \\
\hline $\begin{array}{l}\text { Beef and } \\
\text { mutton }\end{array}$ & 82399.8 & 57679.86 & 158 & 79 & 79 & 40 \\
\hline Poultry & 62780.8 & 43946.56 & 120 & 60 & 60 & 30 \\
\hline Eggs & 102999.8 & 72099.83 & 198 & 99 & 99 & 49 \\
\hline Vegetables & 480175 & 336122.5 & 921 & 460 & 460 & 230 \\
\hline Fruits & 194718.6 & 136303 & 373 & 187 & 187 & 93 \\
\hline $\begin{array}{c}\text { Milk } \\
\text { products }\end{array}$ & 221694.7 & 155186.3 & 425 & 213 & 213 & 106 \\
\hline $\begin{array}{l}\text { Aquatic } \\
\text { products }\end{array}$ & 48066.55 & 33646.59 & 92 & 46 & 46 & 23 \\
\hline Total & 1453768 & 1017638 & 2788 & 1394 & 1394 & 697 \\
\hline
\end{tabular}

Table 6. The theoretical value of refrigerated cars needed within the forth-loop roads in Beijing (according to per capita consumption)

\section{The demand of refrigerated cars calculated via wholesale markets trading volume}

From Table 7, the demand for related cold chain food is 21.57 million tons in 2010. According the assumption, the goods tonnage of needed all kinds of refrigerated trucks per year exceeds 6.12 million tons. The number of required refrigerated cars is listed in Table 7:

\begin{tabular}{|c|c|c|c|c|c|c|}
\hline \multirow{2}{*}{$\frac{\text { Cold chain }}{\text { Food }}$} & \multirow{2}{*}{$\begin{array}{l}\text { The whole } \\
\text { traffic volume } \\
\text { of cold chain(t) }\end{array}$} & \multirow{2}{*}{$\begin{array}{l}\text { Traffic volume } \\
\text { within the forth- } \\
\text { loop roads(t) }\end{array}$} & \multicolumn{2}{|c|}{$\begin{array}{l}\text { The number of refrigerated } \\
\text { cars (1t)needed(volume) }\end{array}$} & \multicolumn{2}{|c|}{$\begin{array}{l}\text { The number of refrigerated } \\
\text { cars }(2 \mathrm{t}) \text { needed(volume) }\end{array}$} \\
\hline & & & $\begin{array}{l}\text { Distribution } \\
\text { once per day }\end{array}$ & $\begin{array}{l}\text { Distribution } \\
\text { twice per day }\end{array}$ & $\begin{array}{l}\text { Distribution } \\
\text { once per day }\end{array}$ & $\begin{array}{c}\text { Distribution } \\
\text { twice per } \\
\text { day }\end{array}$ \\
\hline Pork & 388542 & 271979.4 & 745 & 373 & 373 & 186 \\
\hline $\begin{array}{l}\text { Beef and } \\
\text { mutton }\end{array}$ & 88080 & 61656 & 169 & 84 & 84 & 42 \\
\hline Poultry & 70464 & 49324.8 & 135 & 68 & 68 & 34 \\
\hline Eggs & 60402 & 42281.4 & 116 & 58 & 58 & 29 \\
\hline Vegetables & 176701.5 & 123691.1 & 339 & 169 & 169 & 85 \\
\hline Fruits & 3098626 & 2169038 & 5943 & 2971 & 2971 & 1486 \\
\hline $\begin{array}{l}\text { Milk } \\
\text { products }\end{array}$ & 1872151 & 1310506 & 3590 & 1795 & 1795 & 898 \\
\hline $\begin{array}{l}\text { Aquatic } \\
\text { products }\end{array}$ & 364327 & 255028.9 & 699 & 349 & 349 & 175 \\
\hline Total & 6119294 & 4283506 & 11736 & 5868 & 5868 & 2934 \\
\hline
\end{tabular}

Table7. The theoretical value of refrigerated cars needed within the forth-loop roads in Beijing (according to wholesale markets volume)

According the market trading volume of 2010 and when distribution once and twice per day, the required 1 -ton vehicles are 11,736 and 5,868, while the required 2-ton vehicles are 5,868 and 2,934 respectively. However there're 1,882 1-ton and 2-ton refrigerated cars. So the present refrigerated cars has a big vacancy, which is a reason why part food are not 
transported by refrigerated cars. The vacancy of refrigerated cars limits the development of cold chain logistics and affects the people's living standard.

\subsection{Analysis of demand forecast of refrigerated warehouse}

\section{The theoretical value of max warehouse of the existing refrigerated warehouse}

In the investigation, we found that the turnover rate of the existing refrigerated warehouse is more than 30 days. The stored goods of annual turnover are only about 1,095 million tons, and it's under the max warehouse of 900,000 tons of the existing refrigerated warehouse. So if the turnover period is 30 days, which is far from being able to meet the demand of refrigerated warehouse in Beijing.

We can learn about the uniform calculating method of refrigerated warehouse capacity which is reached by national refrigerated warehouse business innovation and energy saving seminars: The national refrigerated warehouse capacity will be calculated with nominal volume in units of cubic meters in three years. In order to facilitate the statistics, the calculated density of freezing food in the refrigerated warehouse is set to 0.3 ton/cubic meter, and the calculated density of cooling food in the refrigerated warehouse is set to 0.15 tons/cubic meter. At the same time, the food has gone through at least two links in the circulation (such as directly from the manufacturer to the retail in the simplest commodity circulation process), and food in every process should be stored for a long or short time, so that tonnage of the refrigerated warehouse may be considered at least twice as big as the tonnage of the food which needs to be stored. The author's research showed that some resources of the refrigerated warehouse were occupied by some other things such as the channels, the actual utilization of the refrigerated warehouse is $80 \%$ of its theoretical value, so the theoretical value of the refrigerated warehouse needs should be assumed for more than 1.25 times than the tonnage of actual needs. Here, the food which to be stored in the refrigerated warehouse is calculated under the same assumptions as the refrigerated cars, the turnover rate of the inventory is 7 days ,15 days, 30 days and 40 days, and we assume the freezing refrigerated warehouse and the cooling refrigerated warehouse is half of all the food respectively. The need of refrigerated warehouse is calculated from two aspects which are per capita consumption and wholesale market volume.

\section{The demand of refrigerated warehouse calculated via per capita consumption}

The demand of refrigerated warehouse resources in Beijing is calculated under the above assumption with the example of per capita consumption in 2010.

In the same way, the results calculated via per capita consumption in table 8 is the least demand of refrigerated warehouse of the existing food which needs to be stored. 


\begin{tabular}{|c|r|r|r|r|}
\hline \multirow{2}{*}{ Turnover rate } & \multicolumn{1}{|c|}{$7 \mathrm{~d}$} & \multicolumn{1}{c|}{$15 \mathrm{~d}$} & \multicolumn{1}{c|}{$30 \mathrm{~d}$} & \multicolumn{1}{c|}{$40 \mathrm{~d}$} \\
\cline { 2 - 5 } & capacity & capacity & capacity & capacity \\
\hline pork & 62552 & 134041 & 268082 & 357442 \\
\hline beef & 19753 & 42329 & 84657 & 112876 \\
\hline mutton & 15050 & 32250 & 64501 & 86001 \\
\hline poultry & 24692 & 52911 & 105822 & 141096 \\
\hline eggs & 115110 & 246665 & 493331 & 657774 \\
\hline vegetables & 46679 & 100027 & 200053 & 266738 \\
\hline fruits & 53146 & 113884 & 227769 & 303691 \\
\hline aquatic products & 11523 & 24692 & 49383 & 65845 \\
\hline total & 348506 & 746799 & 1493597 & 1991463 \\
\hline
\end{tabular}

Table 8. The theoretical value of the demand of refrigerated warehouse resources in Beijing (According to the per capita consumption in 2010) (unit of nominal volume is cubic meter)

\section{The need of refrigerated warehouse is calculated via wholesale market volume}

We can learn from table 2 that the total amount of all kinds of food which needs refrigerated warehouse is 2157 tons in Beijing, the demand of refrigerated warehouse in Beijing is calculated in table 9.

\begin{tabular}{|c|r|r|r|r|}
\hline \multirow{2}{*}{ Turnover rate } & \multicolumn{1}{|c|}{$7 \mathrm{~d}$} & \multicolumn{1}{c|}{$15 \mathrm{~d}$} & \multicolumn{1}{c|}{$30 \mathrm{~d}$} & \multicolumn{1}{c|}{$40 \mathrm{~d}$} \\
\cline { 2 - 5 } & capacity & capacity & capacity & capacity \\
\hline pork & 93144 & 199593 & 399187 & 532249 \\
\hline beef & 21115 & 45247 & 90493 & 120658 \\
\hline mutton & 16892 & 36197 & 72395 & 96526 \\
\hline poultry & 14480 & 31028 & 62057 & 82742 \\
\hline eggs & 42360 & 90771 & 181543 & 242057 \\
\hline vegetables & 742821 & 1591760 & 3183520 & 4244693 \\
\hline fruit & 448803 & 961721 & 1923443 & 2564590 \\
\hline aquatic products & 87339 & 187154 & 374309 & 499078 \\
\hline total & 1466954 & 3143473 & 6286946 & 8382594 \\
\hline
\end{tabular}

Table 9. The theoretical value of demand of refrigerated warehouse resources in Beijing (According to the market volume in 2010) (unit of nominal volume is cubic meter)

We can see the demand of refrigerated warehouse in different turnover rate in table 9. Through the author's research, we can see that the turnover rate of the existing refrigerated warehouse is mostly over 30 days, there is more than 1.25 million tons of refrigerated warehouse needed if the turnover rate is 30 days from the two tables above, but the capacity of the existing refrigerated warehouse is $0.70 \sim 0.90$ million tons; on the other hand, the annual turnover of stored goods is only about $10.95(<21.57)$ million tons under the max warehouse of 0.90 million tons of the existing refrigerated warehouse if the turnover period is 30 days. We can see that the existing refrigerated warehouse resources can hardly meet the daily need in Beijing from the comparison above; it is even harder to promise enough refrigerated warehouse in some special situations such as on holidays. Apart from this, we can learn in the paper that the ratio of the need of refrigerated warehouse between all kinds of food is about 55 (pork); 13 (beef); 10 (mutton); 9 (poultry); 25 (eggs); 440 (vegetables); 266 (fruits); 52 (aquatic products), it can be concluded that fresh vegetables and fruits occupied most of the resources, but the refrigerated warehouse which used to store fresh 
vegetables and fruits does not develop well, many fresh vegetables and fruits are not stored in the refrigerated warehouse, it make fresh vegetables and fruits spoiled. So this is the main point of the future development of refrigerated warehouse.

\section{Conclusions}

The purpose of food cold chain logistics is to ensure food quality, the core requirements of food cold chain logistics is to keep low temperatures, so it is more complex and its demand is higher than the common logistics system in the average temperature, the construction of food cold chain logistics needs more investment compared with the common logistics system in the average temperature, and it is a huge systems engineering. From the analysis of the paper, we can see that the need of cold chain logistics grows rapidly, but most consumers are lack of the awareness of the importance of the cold chain and many companies cannot bear the huge investment, it make the gap of the resources of cold chain logistics large and cannot meet the normal need of cold chain logistics in Beijing. Due to the lack of resources of cold chain logistics, on the one hand, it limits the development of cold chain logistics in Beijing, on the other hand, it results in the food which should be transferred by refrigerated cars transported by room temperature vehicles and stored in room temperature, it constitutes food loss and affect the quality of people's lives.

Cold chain logistics in Beijing walk in the forefront in China, but there is still much space for improvement. Only the development of cold chain logistics meets the actual needs, it can ensure the whole community develop cooperatively and improve people's lives and the economic benefits.

\section{Acknowledgment}

This work has been supported by the Beijing Municipal Science \& Technology Commission's project (Z111105000111010-3) and the Foundation of Beijing Jiaotong University (2011JBM233).

\section{References}

Fang, Y., Gao, G., \& Fan, X. (2005). Research on food safety traceability system in China. Agricultural Quality and Standards. 2, 37-39.

Hua, Y. (2010). Discussion on the cooperation mode of Super-agriculture Docking. Cooperative Economics. 9: 63-66.

GB/T 18354-2006. Glossary of Logistics. (2007). Beijing: Standards Press of China. 
Liu, L.. \& Qiu, J. (2007).The major aspects of the status quo and development trend of the Shanghai cold chain logistics. Refrigeration technology, 2, 5-8.

Su, L., \& Li, H. (2007). Developing situation and problems of the city Cold Chain Logistics. Market Modernization, 525, 2-3.

Journal of Industrial Engineering and Management, 2013 (www.jiem.org)

El artículo está con Reconocimiento-NoComercial 3.0 de Creative Commons. Puede copiarlo, distribuirlo y comunicarlo públicamente siempre que cite a su autor y a Intangible Capital. No lo utilice para fines comerciales. La licencia completa se puede consultar en http://creativecommons.org/licenses/by-nc/3.0/es/ 